\title{
Combination of 1-Methylcyclopropene and Ethoxyquin to Control Superficial Scald of 'Anjou' Pears
}

\author{
Jinhe Bai ${ }^{1,5}$, Xinhua Yin ${ }^{2}$, Bruce D. Whitaker ${ }^{3}$, Kristi Deschuytter ${ }^{4}$, \\ and Paul M. Chen ${ }^{4}$
}

AdDitional INDEX words. Pyrus communis, l-MCP, $\alpha$-farnesene, conjugated trienes, ripening, extractable juice

Summary. Superficial scald of 'Anjou' pears ( Pyrus communis) usually develops after cold storage of $\geq \mathbf{3}$ months. Ethoxyquin has been used to control scald commercially. However, only a small amount of fruit can be treated within 7 days after harvest as recommended, and sometimes ethoxyquin causes phytotoxicity. Application of 1 methylcyclopropene (1-MCP) showed excellent scald control potential, with rapid and mass treatment feasible. However, fruit may lose normal ripening ability at a dosage of 1-MCP as low as $30 \mathrm{~nL} \cdot \mathrm{L}^{-1}$, whereas a dosage of $\leq 20 \mathrm{~nL} \cdot \mathrm{L}^{-1}$ is not enough to control scald. In this investigation, 'Anjou' pears treated with $25 \mathrm{~nL} \cdot \mathrm{L}^{-1} \mathrm{l}-\mathrm{MCP}$ immediately after harvest were stored at $-1{ }^{\circ} \mathrm{C}$ for up to 5 months. After $1,7,30$, or 60 days of cold storage, part of the fruit were treated with $1000 \mu \mathrm{L} \cdot \mathrm{L}^{-1}$ ethoxyquin and the remainder was left untreated as nonethoxyquin controls. The incidence of superficial scald, the concentrations of $\alpha$-farnesene and its conjugated triene (CT) oxidation products, and the ripening ability of fruit were measured after 3-, 4-, and 5 -month storages. All fruit ripened properly within 7 days of shelf life at $20{ }^{\circ} \mathrm{C}$ regardless of treatment. 1-MCP treatment at harvest or ethoxyquin alone applied within 7 days adequately controlled scald for only 3 months. By contrast, 1-MCP + ethoxyquin controlled scald for $\mathbf{5}$ months, regardless of when ethoxyquin was applied from 1 to 60 days after the start of cold storage. Thus, a combination of 25 $\mathrm{nL} \cdot \mathrm{L}^{-1} \mathbf{l}-\mathrm{MCP}$, which is easily applied and does not influence ripening ability, and a delayed application (up to 60 days) of $1000 \mu \mathrm{L} \cdot \mathrm{L}^{-1}$ ethoxyquin, which is a low dosage that does not cause phytotoxicity on fruit, controlled scald sufficiently. Scald is linked with accumulation of CT oxidation products of $\alpha$-farnesene. 1-MCP and ethoxyquin inhibited accumulation of CT in fruit peel by different mechanisms. 1MCP inhibited the production by reducing $\alpha$-farnesene synthesis and the oxidation to $\mathrm{CT}$, whereas ethoxyquin worked by inhibiting the latter.

S uperficial scald is a major physiological disorder of 'Anjou' pears that occurs after $\geq 3$ or 5 months of cold storage in air or controlled

This research was supported partially by funding from the Washington Tree Fruit Research Commission and by the Columbia Gorge Fruit Growers Association.

The mention of a trademark or proprietary product is for identification only and does not imply a guarantee or warranty of the product by the U.S. Department of Agriculture. The U.S. Department of Agriculture prohibits discrimination in all its programs and activities on the basis of race, color, national origin, gender, religion, age, disability, political beliefs, sexual orientation, and marital or family status.

${ }^{1}$ Citrus and Subtropical Products Laboratory, U.S. Department of Agriculture-Agricultural Research Service, Winter Haven, FL 33881.

${ }^{2}$ Department of Plant Sciences, The University of Tennessee, Jackson, TN 38301.

${ }^{3}$ Produce Quality and Safety Laboratory, U.S. Department of Agriculture-Agricultural Research Service, Beltsville, MD 20705

${ }^{4}$ Mid-Columbia Agricultural Research and Extension Center, Oregon State University, Hood River, OR 97031 .

${ }^{5}$ Corresponding author. E-mail: Jinhe.bai@ars.usda. gov. atmosphere (CA), respectively (Hansen and Mellenthin, 1979). The commercial air storage target for 'Anjou' pears is typically $\mathbf{5}$ months; longer storage requires $\mathrm{CA}$. The primary means of controlling superficial scald on 'Anjou' pears is a postharvest treatment with ethoxyquin. Ethoxyquin is labeled to be applied at a concentration of $2700 \mu \mathrm{L} \cdot \mathrm{L}^{-1}$ within $7 \mathrm{~d}$ after harvest for complete scald control. Commercial ethoxyquin application options include drenching, line spraying, or wrapping with impregnated paper. Drenching may cause phytotoxicity at $1350 \mu \mathrm{L} \cdot \mathrm{L}^{-1}$ or above because of accumulation and consequent concentration of the chemical solution in the contact points between fruit, and between fruit and the container wall (Chen, 2004). Line spray or paper wrap application can avoid phytotoxicity. However, commercial packinghouses are capable of treating only a small amount of fruit within $7 \mathrm{~d}$ of harvest. Therefore, alternative methods for controlling superficial scald are needed by the 'Anjou' pear industry.

l-MCP is a potential alternative for controlling superficial scald of 'Anjou' pears (Argenta et al., 2003; Bai et al., 2006; Chen and Spotts, 2005; Gapper et al., 2006). However, Chen and Spotts (2005) reported that when 1-MCP dosages were 30 $\mathrm{nL} \cdot \mathrm{L}^{-1}$ or higher, fruit lost normal ripening ability; on the other hand, when $1-\mathrm{MCP}$ dosages were $20 \mathrm{~nL} \cdot \mathrm{L}^{-1}$ or lower, superficial scald was not controlled after 4 months of cold storage. Without 1-MCP treatment, 'Anjou' pears generally remain firm during cold storage, and ripen within $7 \mathrm{~d}$ after transferring to room temperature if their conditioning requirement has been satisfied (Chen, 2004).

In this study, combinations of a low dosage 1-MCP treatment at harvest and a delayed low-dose ethoxyquin treatment were tested with respect to scald control and ripening capacity. We selected $25 \mathrm{~nL} \cdot \mathrm{L}^{-1}$ as the

\begin{tabular}{llll}
\hline $\begin{array}{l}\text { Units } \\
\text { To convert U.S. to SI, } \\
\text { multiply by }\end{array}$ & U.S. unit & SI unit & $\begin{array}{l}\text { To convert SI to U.S., } \\
\text { multiply by }\end{array}$ \\
\hline 29.5735 & $\mathrm{fl} \mathrm{oz}$ & $\mathrm{mL}$ & 0.0338 \\
104.3176 & $\mathrm{fl} \mathrm{oz} / \mathrm{oz}$ & $\mathrm{mL} / 100 \mathrm{~g}$ & 0.0096 \\
0.3048 & $\mathrm{ft}$ & $\mathrm{m}$ & 3.2808 \\
0.0283 & $\mathrm{ft}^{3}$ & $\mathrm{~m}^{3}$ & 35.3147 \\
3.7854 & $\mathrm{gal}$ & $\mathrm{L}$ & 0.2642 \\
2.54 & inch $(\mathrm{es})$ & $\mathrm{cm}$ & 0.3937 \\
25.4 & inch $(\mathrm{es})$ & $\mathrm{mm}$ & 0.0394 \\
6.4516 & inch & $\mathrm{cm}$ & 0.1550 \\
0.4536 & lb & $\mathrm{kg}$ & 2.2046 \\
4.4482 & $\mathrm{lbf}$ & $\mathrm{N}$ & 0.2248 \\
25.4 & $\mathrm{mil}$ & $\mu \mathrm{m}$ & 0.0394 \\
28.3495 & $\mathrm{oz}$ & $\mathrm{g}$ & 0.0353 \\
1 & $\mathrm{ppb}$ & $\mathrm{nL} \cdot \mathrm{L}^{-1}$ & 1 \\
1 & $\mathrm{ppm}$ & $\mu \mathrm{L} \cdot \mathrm{L}^{-1}$ & 1 \\
$\left({ }^{\circ} \mathrm{F}-32\right) \div 1.8$ & ${ }^{\circ} \mathrm{F}$ & ${ }^{\circ} \mathrm{C}$ & $\left(1.8 \times{ }^{\circ} \mathrm{C}\right)+32$ \\
& & & \\
\hline
\end{tabular}

Hortlechnology · July-September 2009 19(3) 
1-MCP dosage because this treatment controlled scald for 3 months and did not affect ripening (Bai et al., 2006). The objective was to establish a protocol whereby the industry can treat 'Anjou' pears with 1-MCP quickly to avoid crowded packing lines during harvest, and subsequently treat with ethoxyquin and pack the fruit after up to 2 months of storage, providing scald control for up to 5 months in air at $-1{ }^{\circ} \mathrm{C}$.

\section{Materials and methods}

SOURCE OF FRUIT AND TREATMENTS. 'Anjou' pears were harvested at commercial maturity in 2003 and 2004 from an orchard at Oregon State University, MidColumbia Agricultural Research and Extension Center, Hood River. Flesh firmness averaged $62 \pm 3 \mathrm{~N}$ and $66 \pm 3$ $\mathrm{N}$ in 2003 and 2004, respectively. Defect-free fruit were randomly packed in 45-lb wooden boxes with perforated polyethylene liners $(0.8 \mathrm{mil}$ thick, 100 1/4-inch-diameter holes). Every box contained 70 to 80 fruit.

In 2003 and 2004, 90 boxes of fruit were divided into two groups: half were treated with 1-MCP immediately after harvest and the other half were left as non-1-MCP controls. For 1-MCP treatment, 45 boxes of fruit were placed in a $40-\mathrm{m}^{3}$ air-tight room and fumigated with 25 $\mathrm{nL} \cdot \mathrm{L}^{-1}$ 1-MCP (Smartfresh ${ }^{\mathrm{TM}}$; AgroFresh, Spring House, PA) for $24 \mathrm{~h}$ at $20{ }^{\circ} \mathrm{C}$ according to the manufacturer's instructions. During the treatment, an electric fan was used to distribute 1-MCP evenly in the room. 1-MCP-treated fruit were then transferred to an open room and ventilated with electric fans for $24 \mathrm{~h}$ at $20^{\circ} \mathrm{C}$. Fruit with or without 1-MCP treatment were then transferred to $-1{ }^{\circ} \mathrm{C}$ storage for up to 5 months. After 1, 7, 30 , and $60 \mathrm{~d}$ of cold storage, nine boxes each of 1-MCP-treated fruit and non-1-MCP-treated fruit were treated with ethoxyquin (1000 $\mu \mathrm{L} \cdot \mathrm{L}^{-1}$; Decco Cerexagri, Monrovia, CA). Ethoxyquin treatment was applied by drenching at $10^{\circ} \mathrm{C}$ for 30 $s$ and fruit were returned to cold storage immediately thereafter. Fruit receiving no ethoxyquin treatment served as the controls.

After 3, 4, and 5 months of storage, three replicate boxes of fruit from each treatment were removed

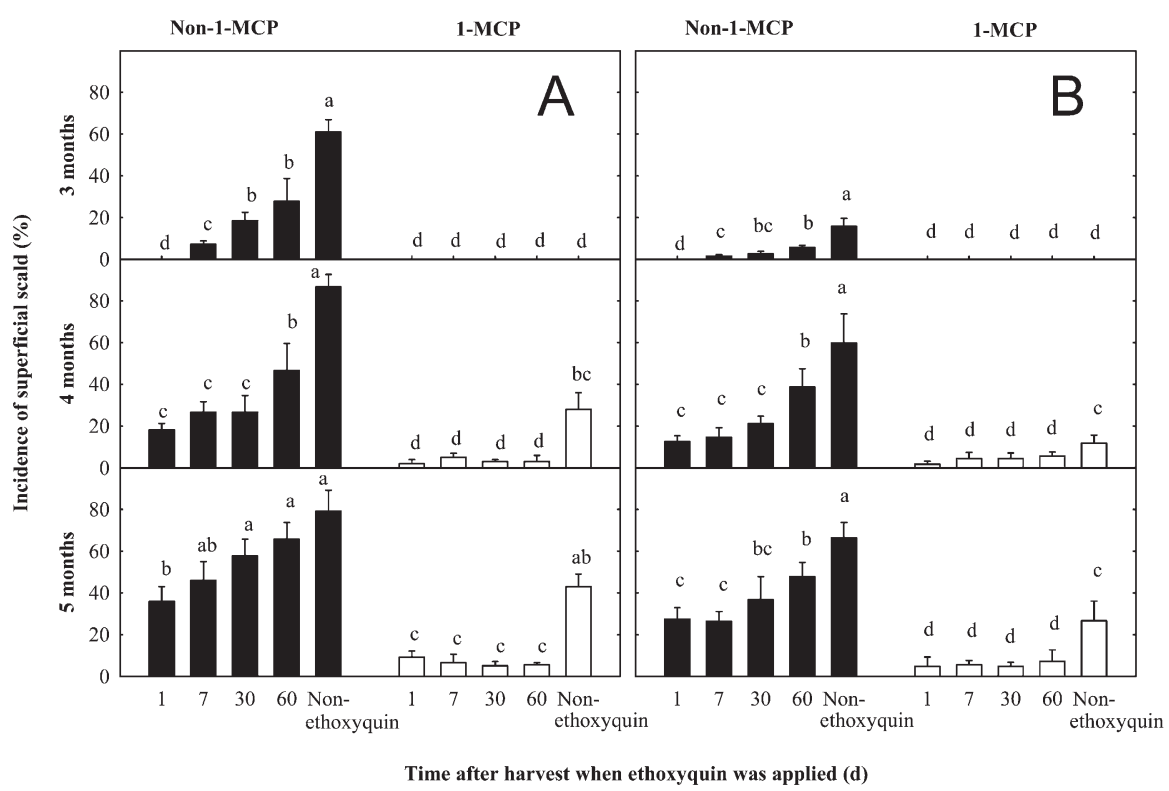

Fig. 1. Effect of 1-methylcyclopropene (1-MCP) and ethoxyquin treatments on superficial scald of 'Anjou'pears in the 2003 (A) and 2004 (B) harvest seasons. Fruit were untreated (solid) or treated (open) with $25 \mathrm{~nL} \cdot \mathrm{L}^{-1}$ (ppb) 1-MCP for $24 \mathrm{~h}$ immediately after harvest and then stored at $-1{ }^{\circ} \mathrm{C}\left(30.2{ }^{\circ} \mathrm{F}\right)$ for up to 5 months. Ethoxyquin drench $\left[1000 \mu \mathrm{L} \cdot \mathrm{L}^{-1}(\mathrm{ppm})\right]$ was applied after $1,7,30$, or $60 \mathrm{~d}$ of cold storage or was not applied (nonethoxyquin). Superficial scald was evaluated after 3 , 4 , or 5 months of storage in air at $-1^{\circ} \mathrm{C}$ followed by $7 \mathrm{~d}$ of shelf life at $20^{\circ} \mathrm{C}(68.0$ $\left.{ }^{\circ} \mathrm{F}\right)$. Vertical lines represent standard deviation (three replicates). Within the same storage time (sampling day), vertical bars labeled with the same letter are not significantly different at $\boldsymbol{P}=\mathbf{0 . 0 5}$ using Duncan's multiple range test. from cold storage and held at $20^{\circ} \mathrm{C}$ for $7 \mathrm{~d}$ before evaluation.

EVALUATION OF RIPENING BEHAVIOR AND SUPERFICIAL SCALD. Ripening behavior and superficial scald were evaluated by measuring flesh firmness (FF) and visually determining scald incidence.

Superficial scald was classified according to the fruit surface area affected by scald in which $0.5 \mathrm{~cm}^{2}$ or less scald area = very slight; 0.6 to 1.0 $\mathrm{cm}^{2}=$ slight; 1.1 to $3.0 \mathrm{~cm}^{2}=$ moderate; and greater than $3.0 \mathrm{~cm}^{2}=$ severe. Scald was evaluated on 70 to 80 fruit per box, and those scored from slight to severe were considered commercially unacceptable.

FF was measured using a fruit texture analyzer (model GS-14; Guss Manufacturing, Strand, South Africa). Ten fruit per box were tested with an 8 -mm plunger that penetrates $9 \mathrm{~mm}$ in $0.9 \mathrm{~s}$ and the force values were recorded in newtons. Two measurements were obtained per fruit from opposite sides at the equator where $20-\mathrm{mm}^{-}$ diameter peel discs were first removed.

Ethylene production, $\alpha$ FARNESENE AND CONJUGATED TRIENES, EXTRACTABLE JUICE (EJ), SOLUbLE SOLIDS CONTENT (SSC), AND TITRATABLE ACIDITY (TA) MEASUREMENTS. Ethylene production was determined using a flow-through system. A 10fruit ( $\approx 2100 \mathrm{~g}$ ) sample was removed from cold storage and placed into a 10-L chamber flushed with humidified air at a flow rate of $150 \mathrm{~mL} / \mathrm{min}$ at $20{ }^{\circ} \mathrm{C}$ for $7 \mathrm{~d}$. Gas samples were taken from the outlet of the chamber using a syringe and injected into a gas chromatograph (GC-9A; Shimadzu, Kyoto, Japan) with a flame ionization detector (FID) and a Porapack Q column $(80 / 100$ mesh, $1.83 \mathrm{~m} \times 3.2 \mathrm{~mm}$ i.d.; Alltech, Deerfield, IL), and the peak response was calibrated against an external standard of ethylene (1.0 $\left.\mu \mathrm{L} \cdot \mathrm{L}^{-1}\right)$.

$\alpha$-Farnesene and CT were measured immediately after cold storage using a spectrophotometer (model DU 64; Beckman, Fullerton, CA). Peel tissue (including the epidermis and $2-3 \mathrm{~mm}$ of hypodermal cortex) from five fruit was excised with a stainless steel fruit peeler. Tissue samples $(5 \mathrm{~g}$ ) were then extracted in 25 $\mathrm{mL}$ of hexane (HPLC-grade; Fisher Scientific, Fair Lawn, NJ) in a covered beaker. The beaker with tissue and hexane was shaken with an orbital 
shaker (VSOS-4P; PRO Scientific, Oxford, CT) at $120 \mathrm{rpm}$ and $20^{\circ} \mathrm{C}$ for $3 \mathrm{~min}$. The hexane extracts were diluted as required and then scanned for ultraviolet absorbance between 190 and $300 \mathrm{~nm}$ at 2 -nm intervals. $\alpha$-Farnesene and CT, respectively, were quantified from the absorbance values at $232 \mathrm{~nm}\left(\mathrm{~A}_{232}\right)$ and $\mathrm{A}_{281}-$ $\mathrm{A}_{290}$, using the published molar extinction coefficients $\mathrm{E}_{232}=27,700$ and $E_{281-290}=25,000$ (Anet, 1972; Du and Bramlage, 1993; Huelin and Coggiola, 1968; Whitaker et al., 1997).

EJ was obtained from $100 \mathrm{~g}$ of flesh tissue sampled from five fruit (peel and core removed) per replicate. A juicer (model 6001; Acme Juicer, Sierra Madre, CA) was used with a milk filter (Schwartz, Two Rivers, WI) at about 2500 to $3000 g_{n}$ for 1 min and the juice volume was measured in a $100-\mathrm{mL}$ graduated cylinder (Chen and Mellenthin, 1981).

SSC and TA were measured using EJ. SSC was measured with a refractometer (model Nl; Atago, Tokyo). TA was determined by titrating a mixture of $10 \mathrm{~mL}$ of juice and $40 \mathrm{~mL}$ of ion-free water with 0.1 normal sodium hydroxide to $\mathrm{pH} 8.1$ using a titration system (model T80/20; Schott-Gerate, Hofheim, Germany).

Data ANALYsis. The experiments were conducted using a completely randomized design with three replicates. SAS (version 8; SAS Institute, Cary, NC) was used to analyze the data, including the incidence of superficial scald, FF, $\alpha$-farnesene and CT concentrations, ethylene production, SSC, and TA, using analysis of variance (PROC ANOVA). Mean separation was determined by Duncan's multiple range test at the $5 \%$ level.

\section{Results and discussion}

SCALD CONTROL. Ethoxyquin applied $1 \mathrm{~d}$ after harvest completely controlled superficial scald after 3 month storage in the 2003 and 2004 seasons, but scald incidence increased to over $18 \%$ and $13 \%$ after 4 months of cold storage in 2003 and 2004, respectively (Fig. 1). According to the U.S. standards for winter pears (Chen, 2004), no more than a total of $10 \%$ of the fruit are allowed to

Table 1. Effects of 1-methylcyclopropene (1-MCP) and ethoxyquin on $\alpha$-farnesene and the conjugated trienes (CT) levels, flesh firmness, extractable juice, and titratable acidity of 'Anjou' pears in the 2003 harvest season. Fruit were treated or untreated with $25 \mathrm{~nL} \cdot \mathrm{L}^{-1}$ (ppb) 1-MCP for $24 \mathrm{~h}$ immediately after harvest and then stored at $-1{ }^{\circ} \mathrm{C}\left(30.2{ }^{\circ} \mathrm{F}\right)$ for up to 5 months. Ethoxyquin drench $\left[1000 \mu \mathrm{L} \mathrm{L}^{-1}(\mathrm{ppm})\right]$ was applied after 1, 7, 30, or $60 \mathrm{~d}$ of cold storage. $\alpha$-Farnesene and CT were measured immediately after cold storage, and other attributes were measured after a 7 -d shelf life at $20{ }^{\circ} \mathrm{C}\left(68.0{ }^{\circ} \mathrm{F}\right)$.

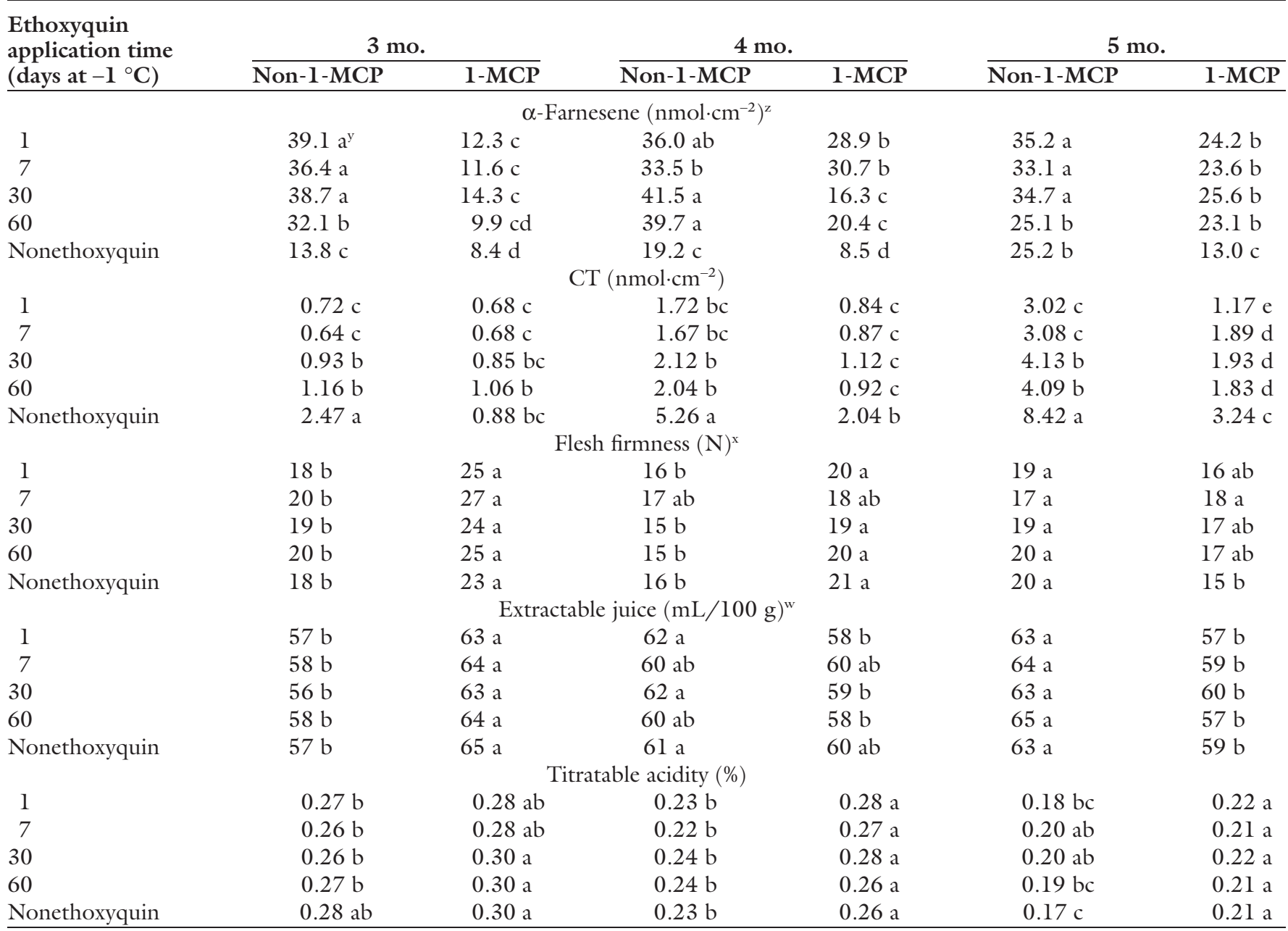

${ }^{\mathrm{z}} 1 \mathrm{nmol} \cdot \mathrm{cm}^{-2}=6.4516 \mathrm{nmol} / \mathrm{inch}^{2}$.

${ }^{y}$ Average (three replicates) labeled with the same letter within the same storage time are not significantly different at $P=0.05$ using Duncan's multiple range test.

${ }^{x} 1 \mathrm{~N}=0.2248 \mathrm{lbf}$.

" $1 \mathrm{~mL} / 100 \mathrm{~g}=0.0096 \mathrm{fl} \mathrm{oz} / \mathrm{oz}$. 
have defects, such as decay, superficial scald, and other internal or surface disorders. Therefore, ethoxyquin at $1000 \mu \mathrm{L} \cdot \mathrm{L}^{-1}$ failed to control scald after 4 months of storage. Ethoxyquin applied $7 \mathrm{~d}$ after the start of cold storage controlled scald to $7.2 \%$ and $2.5 \%$ after 3 months of storage in the 2003 and 2004 seasons, respectively (Fig. 1). This is a significant drop of ethoxyquin efficiency in scald control compared with ethoxyquin application made $1 \mathrm{~d}$ after harvest. Ethoxyquin failed to control scald if the application was conducted after $30 \mathrm{~d}$ or longer in cold storage in 2003 (Fig. 1A). In the 2004 season (Fig. 1B), scald incidence was generally lower than in 2003 for all treatments and the control, however, it is still clear that the later ethoxyquin was applied the lower its efficiency was in scald control.

1-MCP application controlled scald completely after a 3-month cold storage in both years, regardless of whether an ethoxyquin drench was also applied (Fig. 1). However, treatment of pears with 1-MCP alone did not control scald after cold storage for 4 months (Fig. 1). The combinations of ethoxyquin and 1-MCP treatments controlled scald for up to 5 months, although scald occurred in 5\% to $9 \%$ of the fruit (Fig. 1). A delayed application of ethoxyquin (up to $60 \mathrm{~d}$ ) was equally effective in scald control, if not better, compared with the labelrecommended applications within $7 \mathrm{~d}$ after harvest (Fig. 1). However, the label-recommended concentration of $2700 \mu \mathrm{L} \cdot \mathrm{L}^{-1}$ was not tested; only the lower concentration of $1000 \mu \mathrm{L} \cdot \mathrm{L}^{-1}$ was used in these experiments. Thus, with a $25 \mathrm{~nL} \cdot \mathrm{L}^{-1} \mathrm{l}$-MCP treatment, which can be rapidly applied to a large quantity of fruit, a delayed (up to 60 d) and reduced dosage application of ethoxyquin was effective to control scald.

Many publications show a strong correlation between scald incidence and the level of oxidation products of $\alpha$-farnesene (Anet, 1972; Du and Bramlage, 1993; Gapper et al., 2006; Huelin and Coggiola, 1968; Whitaker et al., 1997). Ethoxyquin treatment increased $\alpha$-farnesene accumulation but decreased CT content in pear peel tissue (Tables 1 and 2),

Table 2. Effects of 1-methylcyclopropene (1-MCP) and ethoxyquin on $\alpha$-farnesene and the conjugated trienes (CT) levels, flesh firmness, extractable juice, and titratable acidity of 'Anjou' pears in the 2004 harvest season. Fruit were treated or untreated with $25 \mathrm{~nL} \cdot \mathrm{L}^{-1}$ (ppb) 1-MCP for $24 \mathrm{~h}$ immediately after harvest and then stored at $-1{ }^{\circ} \mathrm{C}\left(30.2^{\circ} \mathrm{F}\right)$ for up to 5 months. Ethoxyquin drench $\left[1000 \mu \mathrm{L} \cdot \mathrm{L}^{-1}(\mathrm{ppm})\right]$ was applied after 1, 7, 30, or $60 \mathrm{~d}$ of cold storage. $\alpha$-Farnesene and CT were measured immediately after cold storage, and other attributes were measured after a 7 -d shelf life at $20{ }^{\circ} \mathrm{C}\left(68.0{ }^{\circ} \mathrm{F}\right)$.

\section{Ethoxyquin}

application time

3 mo.

$4 \mathrm{mo}$.

(days at $-1^{\circ} \mathrm{C}$ )

Non-1-MCP
$37.4 \mathrm{a}^{\mathrm{y}}$
$38.6 \mathrm{a}$
$35.4 \mathrm{a}$
$33.1 \mathrm{a}$
$14.9 \mathrm{~b}$
$0.22 \mathrm{~d}$
$0.43 \mathrm{c}$
$0.48 \mathrm{c}$
$1.63 \mathrm{ab}$
$2.18 \mathrm{a}$

Nonethoxyquin

$20 \mathrm{~b}$

$20 \mathrm{~b}$

$17 \mathrm{~b}$

30

60

Nonethoxyquin

$19 \mathrm{~b}$

$19 \mathrm{~b}$

$156 \mathrm{~b}$

$7 \quad 58 \mathrm{~b}$

$30 \quad 56 \mathrm{~b}$

$60 \quad 56 \mathrm{~b}$

Nonethoxyquin $\quad 57 \mathrm{~b}$

$1 \quad 0.31 \mathrm{ab}$

$7 \quad 0.28 \mathrm{~b}$

30

60

$0.30 \mathrm{~b}$

$0.29 \mathrm{~b}$

Nonethoxyquin

$0.30 \mathrm{~b}$

P $1-M C P$

Non-1-MCP 1-MCP

$\alpha$-Farnesene $\left(\mathrm{nmol} \cdot \mathrm{cm}^{-2}\right)^{\mathrm{z}}$

$11.8 \mathrm{~b}$

$11.6 \mathrm{~b}$

$12.9 \mathrm{~b}$

$11.6 \mathrm{~b}$

$10.7 \mathrm{~b}$

$0.44 \mathrm{~cd}$
$0.47 \mathrm{c}$
$0.74 \mathrm{bc}$
$0.58 \mathrm{c}$

$1.12 \mathrm{~b}$

Flesh firmness

$26 \mathrm{a}$
$27 \mathrm{a}$
$27 \mathrm{a}$
$25 \mathrm{a}$

26 a

Extractable juice $(\mathrm{mL} / 100 \mathrm{~g})^{\mathrm{w}}$

\section{3 a}

63 a

$62 \mathrm{a}$

$64 \mathrm{a}$

$64 \mathrm{a}$

$38.7 \mathrm{a}$
$35.4 \mathrm{a}$
$37.7 \mathrm{a}$
$38.9 \mathrm{a}$
$20.8 \mathrm{~b}$

CT $\left(\mathrm{nmol} \cdot \mathrm{cm}^{-2}\right)$

$1.24 \mathrm{~d}$

$1.34 \mathrm{~d}$

$1.12 \mathrm{de}$

$2.94 \mathrm{~b}$

$4.44 \mathrm{a}$

$17 \mathrm{~b}$

$15 \mathrm{~b}$

$16 \mathrm{~b}$

$16 \mathrm{~b}$

$16 \mathrm{~b}$

$59 \mathrm{ab}$

$61 \mathrm{a}$

$62 \mathrm{a}$

$62 \mathrm{a}$

60 a

Titratable acidity (\%)

$\begin{array}{ll}0.33 \mathrm{a} & 0.27 \mathrm{~b} \\ 0.32 \mathrm{a} & 0.25 \mathrm{~b} \\ 0.33 \mathrm{a} & 0.25 \mathrm{~b} \\ 0.31 \mathrm{ab} & 0.26 \mathrm{~b} \\ 0.32 \mathrm{a} & 0.27 \mathrm{~b}\end{array}$

$24.6 \mathrm{~b}$
$25.8 \mathrm{~b}$
$28.7 \mathrm{~b}$
$18.1 \mathrm{~b}$
$9.8 \mathrm{c}$
$0.92 \mathrm{de}$
$0.83 \mathrm{de}$
$0.63 \mathrm{e}$
$1.11 \mathrm{de}$
$1.93 \mathrm{c}$

22 a

21 a

$19 \mathrm{a}$

21 a

22 a

$58 \mathrm{~b}$

$60 \mathrm{a}$

58 b

$59 \mathrm{ab}$

$59 \mathrm{ab}$

$0.30 \mathrm{a}$
$0.29 \mathrm{a}$
$0.29 \mathrm{a}$
$0.31 \mathrm{a}$
$0.30 \mathrm{a}$
5 mo.

\begin{tabular}{l}
5 mo. \\
\hline Non-1-MCP
\end{tabular}

35.5 a

$35.2 \mathrm{a}$

33.9 a

30.1 a

$23.5 \mathrm{~b}$

$3.01 \mathrm{c}$

$2.88 \mathrm{c}$

$3.06 \mathrm{c}$

$4.13 \mathrm{bc}$

$7.13 \mathrm{a}$

$19 \mathrm{a}$

18 a

18 a

$20 \mathrm{a}$

18 a

$62 \mathrm{a}$

64 a

62 a

63 a

$64 \mathrm{a}$

$0.21 \mathrm{~b}$

$0.24 \mathrm{ab}$

$0.21 \mathrm{~b}$

$0.23 \mathrm{~b}$

$0.22 \mathrm{~b}$
$26.4 \mathrm{~b}$

$22.7 \mathrm{~b}$

$24.3 \mathrm{~b}$

$23.6 \mathrm{~b}$

$14.7 \mathrm{c}$

$1.88 \mathrm{~d}$

$1.94 \mathrm{~d}$

$2.00 \mathrm{~d}$

$1.88 \mathrm{~d}$

4.92 b

$18 \mathrm{a}$

$17 \mathrm{a}$

$15 \mathrm{~b}$

$15 \mathrm{~b}$

$17 \mathrm{a}$

$60 \mathrm{~b}$

59 b

58 b

$59 \mathrm{~b}$

$60 \mathrm{~b}$

\section{$0.27 \mathrm{a}$}

$0.26 \mathrm{a}$

0.27 a

$0.25 \mathrm{ab}$ $0.25 \mathrm{ab}$

${ }^{2} 1 \mathrm{nmol} \cdot \mathrm{cm}^{-2}=6.4516 \mathrm{nmol} / \mathrm{inch}^{2}$.

${ }^{y}$ Average (three replicates) labeled with the same letter within the same storage time are not significantly different at $P=0.05$ using Duncan's multiple range test. ${ }^{x} 1 \mathrm{~N}=0.2248 \mathrm{lbf}$.

${ }^{\mathrm{w}} 1 \mathrm{~mL} / 100 \mathrm{~g}=0.0096 \mathrm{fl} \mathrm{oz} / \mathrm{oz}$. 
indicating that ethoxyquin controlled scald by inhibiting the oxidation of $\alpha$ farnesene to CT. This is the same mode of action attributed to the antioxidant diphenylamine (DPA), which is used to control scald in apple (Malus $\times$ domestica) fruit (Anet and Coggiola, 1974; Huelin and Coggiola, 1970). Delayed application of ethoxyquin was significantly less effective in reducing CT accumulation (Tables 1 and 2). 1-MCP application significantly reduced levels of $\alpha$-farnesene as well as CT (Table 1 ), indicating that $1-\mathrm{MCP}$ controlled scald by inhibiting $\alpha$-farnesene synthesis. Gapper et al. (2006) and Pechous et al. (2005) reported that l-MCP reduced synthesis and oxidation of $\alpha$-farnesene at least partly via inhibition of ethylene-induced upregulation of the $\alpha$-farnesene synthase gene, AFS1. Although scald incidence in 2003 was higher than in 2004 (Fig. 1), $\alpha$-farnesene and CT levels were similar in the 2 years (Tables 1 and 2).

Ripening behaviors. All fruit ripened properly to eating quality of $\mathrm{FF}<27 \mathrm{~N}$ within $7 \mathrm{~d}$ of shelf life at room temperature regardless of treatments (Tables 1 and 2). With or without subsequent ethoxyquin treatment, 1-MCP-treated fruit softened more slowly than the control fruit after 3 and 4 months of storage in 2003 and 2004 (Tables 1 and 2). However, all groups of fruit softened similarly after 5 months of storage (Tables 1 and 2). The best eating quality of pears is when FF has decreased to between 14 and $23 \mathrm{~N}$, with extractable juice content of $<65$ $\mathrm{mL} / 100 \mathrm{~g}$ fresh weight $(\mathrm{FW})$ (Chen and Borgic, 1985). The control fruit were of the best quality after 3 months of storage, with EJ $\leq 58$ $\mathrm{mL} / 100$ g FW. Quality decreased during extended storage, as indicated by an increase in EJ to 60 to $62 \mathrm{~mL} /$ $100 \mathrm{~g} \mathrm{FW}$ and 63 to $65 \mathrm{~mL} / 100 \mathrm{~g}$ FW after 4 and 5 months, respectively (Tables 1 and 2). Chen and Borgic (1985) reported that EJ is an objective means for evaluating texture of pears. Water-soluble polyuronides in the flesh increase dramatically during ripening, resulting in an apparent rise in bound water. Those pears that have a buttery and juicy texture usually show a greater decrease in EJ (Chen and Borgic, 1985). 1-
MCP-treated fruit ripened to eating softness, but did not reach the best eating quality after a 3 -month storage, as indicated by a high FF of 23 to $27 \mathrm{~N}$ and high EJ of 63 to $65 \mathrm{~mL} /$ $100 \mathrm{~g} \mathrm{FW}$ (Chen and Borgic, 1985). However, quality was improved after 4 and 5 months of storage, as indicated by $\mathrm{FF}$ of 15 to $21 \mathrm{~N}$ and EJ of 57 to $60 \mathrm{~mL} / 100 \mathrm{~g} \mathrm{FW}$, and was actually better than that of control fruit, especially after 5 months of storage (Tables 1 and 2). Additionally, 1-MCP treatment delayed the loss of TA, regardless of ethoxyquin application (Tables 1 and 2). However, 1-MCP and ethoxyquin treatments, alone or in combination, did not affect SSC (data not shown).

\section{Conclusions}

A $25 \mathrm{~nL} \cdot \mathrm{L}^{-1} \mathrm{l}$-MCP application at $20^{\circ} \mathrm{C}$ for $24 \mathrm{~h}$ on the day of harvest plus an ethoxyquin drench at 1000 $\mu \mathrm{L} \cdot \mathrm{L}^{-1}$ after $1,7,30$, or $60 \mathrm{~d}$ of cold storage controlled superficial scald of 'Anjou' pears stored in air at $-1^{\circ} \mathrm{C}$ for 5 months. 1-MCP alone, or ethoxyquin alone applied after 1 or $7 \mathrm{~d}$ storage at $-1{ }^{\circ} \mathrm{C}$, adequately controlled scald for only 3 months, and delayed ethoxyquin application (30 or $60 \mathrm{~d}$ ) did not control scald. The effects of 1-MCP and ethoxyquin on $\alpha$-farnesene metabolism indicated that 1-MCP controlled scald by inhibiting $\alpha$-farnesene synthesis and oxidation, whereas ethoxyquin worked only by inhibiting of $\alpha$-farnesene oxidation.

\section{Literature cited}

Anet, E.F. 1972. Superficial scald, a functional disorder of stored apples. IX. Effect of maturity and ventilation. J. Sci. Food Agr. 23:763-769.

Anet, E.F. and I.M. Coggiola. 1974. Superficial scald, a functional disorder of stored apples. X. Control of $\alpha$-farnesene autoxidation. J. Sci. Food Agr. 25:293-298.

Argenta, L.C., X. Fan, and J.P. Mattheis. 2003. Influence of 1-methylcyclopropene on ripening, storage life and volatile production by d'Anjou cv. pear fruit. J. Agr. Food Chem. 51:3858-3864.

Bai, J., J.P. Mattheis, and N. Reed. 2006. Re-initiating softening ability of 1 -methylcyclopropene-treated 'Bartlett' and 'd'Anjou' pears after regular air or controlled atmosphere storage. J. Hort. Sci. Biotechnol. 81:959-964.
Chen, P.M. 2004. Pear. In: K.C. Gross, C.Y. Wang, and M. Saltveit (eds.). The commercial storage of fruits, vegetables, and florist and nursery stocks. 6 Jan. 2009. <http://www.ba.ars.usda.gov/ hb66/107pear.pdf>.

Chen, P.M. and D.M. Borgic. 1985. Changes in water-soluble polygalacturonide in the pulp tissue of ripening 'Bosc' pears following cold storage in air or in $1 \%$ oxygen. J. Amer. Soc. Hort. Sci. 110: 667-671.

Chen, P.M. and R.A. Spotts. 2005. Changes in ripening behavior of 1 MCP-treated 'd'Anjou' pears after storage. Intl. J. Fruit Sci. 5:3-18.

Chen, P.M. and W.M. Mellenthin. 1981. Effect of harvest date on ripening capacity and postharvest life of 'd'Anjou' pears. J. Amer. Soc. Hort. Sci. 106:38-42.

Du, Z. and W.J. Bramlage. 1993. A modified hypothesis on the role of conjugated trienes in superficial scald development on stored apples. J. Amer. Soc. Hort. Sci. 118:807-813.

Gapper, N.E., J. Bai, and B.D. Whitaker. 2006. Inhibition of ethylene-induced $\alpha$ farnesene synthase gene PcAFSI expression in d'Anjou pears with 1-MCP reduces synthesis and oxidation of $\alpha$ farnesene and delays development of superficial scald. Postharvest Biol. Technol. 41:225-233.

Hansen, F. and W.M. Mellenthin. 1979. Commercial handling and storage practices for winter pears. Agr. Expt. Sta., Oregon State Univ., Spec. Rpt.

Huelin, F.E. and I.M. Coggiola. 1968. Superficial scald, a functional disorder of stored apples. IV. Effect of variety, maturity, oiled wraps, and diphenylamine on the concentration of $\alpha$-farnesene in the fruit. J. Sci. Food Agr. 19:297-301.

Huelin, F.E. and I.M. Coggiola. 1970. Superficial scald, a functional disorder of stored apples. V. Oxidation of $\alpha$-farnesene and its inhibition by diphenylamine. J. Sci. Food Agr. 21:44-48.

Pechous, S.W., C.B. Watkins, and B.D. Whitaker. 2005. Expression of $\alpha$-farnesene synthase geneAFS 1 in relation to levels of $\alpha$-farnesene and conjugated trienols in peel tissue of scald-susceptible 'Law Rome' and scald-resistant 'Idared' apple fruit. Postharvest Biol. Technol. 35:125-132.

Whitaker, B.D., T. Solomos, and D.J. Harrison. 1997. Quantification of $\alpha$-farnesene and its conjugated trienol oxidation products from apple peel by $\mathrm{Cl} 8$ HPLC with UV detection. J. Agr. Food Chem. 45:760-765. 